\title{
Male-sterile induction method in foxtail millet (Setaria italica)
}

\author{
RIZKI BAGUS NUGROHO, WILLY BAYUARDI SUWARNO, NURUL KHUMAIDA, \\ SINTHO WAHYUNING ARDIE \\ Department of Agronomy and Horticulture, Faculty of Agriculture, Institut Pertanian Bogor. Jl. Meranti, Kampus IPB Dramaga, Bogor 16680, West \\ Java, Indonesia. Tel.: +62-251-8629353, `email: sintho_wa@apps.ipb.ac.id, rizkibagus23@gmail.com
}

Manuscript received: 29 July 2020. Revision accepted: 26 August 2020.

\begin{abstract}
Nugroho RB, Suwarno WB, Khumaida N, Ardie SW. 2020. Male-sterile induction method in foxtail millet (Setaria italica). Biodiversitas 21: 4325-4330. Male-sterile induction is one technique that can be used to prevent selfing in self-pollination plants, especially for plants with small floret. This study aimed to identify an effective male-sterile induction method that can kill pollen while keeping the stigma receptive in foxtail millet (Setaria italica L. Beauv). The experiment was conducted in a greenhouse at the Cikabayan Experimental Station and the Biology and Biophysics Seed laboratory, Dept. of Agronomy and Horticulture, IPB University, Indonesia from October 2018 to February 2019. The experiment consisted of two sub-experiments that were carried out with a split-plot design with four replications. The male-sterile induction method was the main plot, and the genotype was the subplot. The results from the first experiment showed that alcohol, warm water, and maleic hydrazide treatments were effective for killing pollen in the upper panicle and pollination zones. These treatments were also effective in developing unproductive rachis with different effect patterns on panicles. The results from the second experiment showed that warm water treatment and maleic hydrazide could keep the stigma receptive. From both experiments, warm water treatment was recommended for male-sterile induction in foxtail millet because it was effective in killing pollen, inflicting unproductive rachis in the upper panicle and pollination zones, and kept the stigma receptive.
\end{abstract}

Keywords: Foxtail millet, male-sterile induction, plant breeding, pollen, warm water treatment

\section{INTRODUCTION}

Preventing natural self-pollination is an initial step in conducting artificial crossing on self-pollinated plants. At least there are three methods for preventing natural selfpollination, namely, (i) emasculation, (ii) cytoplasmic male-sterile (CMS), and (iii) induction of male-sterile. Emasculation is the removal of stamens from flowers to avoid selfing in self-pollinating plants (Acquaah 2012). Emasculation can be performed on plants with large flowers, such as tomatoes (Sharma et al. 2019). On the other hand, emasculation is highly challenging for plants with tiny flowers or florets such as foxtail millet and other Setaria species, and it takes a considerable amount of time and labor (Rizal et al. 2013). Alternative methods are CMS or male sterile induction.

CMS is a condition of plants with sterile pollen because of the interaction of the rfrf genotype in the nucleus with a sterile gene in the cytoplasm (Acquaah 2012). CMS is caused by mutations in the mitochondrial genome that interfered with the function of mitochondrial gene for pollen development and also can originate from natural or artificial intergeneric or interspecific hybridization and some plant use protoplast fusion (Lin et al. 2017). In foxtail millet, CMS line has been developed with artificial interspecific hybridization from Setaria verticillata $\times$ Setaria italica, but for unknown reason, that line never used to produce hybrid (Doust and Diao 2017). In other side, CMS plants in Indonesia is currently available for rice (Nugraha et al. 2011) and some commercial plant, but not yet for foxtail millet. Therefore, one possible method for preventing selfing in foxtail millet is male-sterile induction.

Male-sterile induction is a pollen killing method applied before anthesis by soaking flowers or florets in warm water or gametocide chemical (Sharma and Sharma 2005). Ethanol $57 \%$ for 10 minutes applied in the alfalfa flower was effective for inducing male sterile (Acquaah 2012). In rice plants, soaking panicles with warm water at $46^{\circ} \mathrm{C}$ for 2.5 minutes was effective for killing pollen (Aguiar et al. 2017). Male-sterile induction has also been carried out on green millet by soaking panicle with warm water at a temperature of $48^{\circ} \mathrm{C}$ for 3-6 minutes (Jiang et al. 2013) or with $500 \mu \mathrm{M}$ maleic hydrazide for 2 minutes (Rizal et al. 2015). Such research has not been extensively conducted for foxtail millet.

The reason why male-sterile induction proper to be tested in foxtail millet is potential traits that need artificial hybridization to combine all the good traits from the different genotypes. Developing a superior variety of foxtail millet from artificial hybridization could fix a nutritional and health issues because it has good nutritional properties in its grain, such high level of protein, carbohydrate, high dietary fiber, mineral essential, and gluten-free (Dhivya et al. 2015; Ambati and Sucharitha 2019; Yin et al. 2019). Besides, its relative tolerance to drought (Ojha et al. 2018) and salinity stress (Islam et al. 2011) are relatively adaptive in some problematic soil. This study aimed to determine an effective male-sterile induction method for foxtail millet. The objective of the first sub-experiment was to identify treatments that can kill pollen effectively, and the purpose of the second sub- 
experiment was to identify treatments that can keep pistil receptive after induction.

\section{MATERIALS AND METHODS}

Two genotypes of foxtail millet from the Indonesian Cereals Research Institute (ICERI) were evaluated, i.e., ICERI-5 and ICERI-6. These genotypes have a relative tolerance to salinity and drought stress, early harvest time (64 days after planting/ DAP), and short stature $(<100 \mathrm{~cm})$ (Ardie et al. 2015; Lapuimakuni et al. 2018; Widyawan et al. 2018), and therefore are potential for breeding. The male-sterile induction could be easily applied to these genotypes because of their short stature.

The study was conducted in a greenhouse at the Cikabayan Experimental Station and Seed Biology and Biophysics Laboratory, Dept. of Agriculture and Horticulture, IPB University, from November 2018 to February 2019. Growing media consisted of a mixture of soil and sand with a volume ratio of $1: 1$ and a $\mathrm{pH}$ of 6.5 in a pot. Fertilizer consisted of urea, SP-36, and $\mathrm{KCl}$ at a ratio of 1: $0.75: 1 \mathrm{~g}$ per pot.

This study consisted of two sub-experiments. The first sub-experiment was the treatment of male-sterile in panicles without trimming and sibbing, and the second subexperiment is the treatment of male-sterile in panicles which had been trimmed at the upper and lower zone of panicles and followed by sibbing (Figure 1.A). Induction was carried out on the second day of the large floret stage in the pollination zone or the fourth day after panicle initiation (Nugroho et al. 2020, unpublished). Sibbing in the second sub-experiment was carried out when anthesis had occurred after male-sterile induction.
Each experiment was arranged in a split-plot design with four replications. The main plot was male-sterile induction (Table 1), and the subplot was genotype. Traits observed on the first sub-experiment were (i) sterile pollen $(\%)$, counted from the total of sterile pollen per total pollen from one floret each panicle zone (Figure 1.C); (ii) the length of the panicle with full seeded $(\%)$, measured from the length of panicle with full seed per total length of panicle multiplied by 100; (iii) the length of the panicle with $50 \%$ seeded $(\%)$, measured from the length of panicle with $50 \%$ seed per total length of panicle multiplied by 100; (iv) the length of the panicle with few seeded (\%), measured from the length of panicle with few seeds per total length of panicle multiplied by 100; (v) unproductive rachis (\%), counted from the rachises below $50 \%$ seeded per total rachises multiplied by 100 (Figure 1.B); and (vi) the area of the floret or seed $\left(\mathrm{mm}^{2}\right)$, measured on the entire surface of the floret with the help of ImageJ software ver. 1.52a each panicle zone. Evaluated traits on the second sub-experiment were (i) sterile pollen (\%); (ii) productive rachis $(\%)$, counted from the rachises with $50-100 \%$ seeded per total rachises multiplied by 100 (Figure 1.B); (iii) the area of floret or seed $\left(\mathrm{mm}^{2}\right)$.

Table 1. Treatment of male-sterile induction for foxtail millet

\begin{tabular}{|c|c|}
\hline Treatment & Reference \\
\hline Control & - \\
\hline Induction with alcohol ( $70 \%)$ for 5 & Acquaah (2012); \\
\hline minutes & Rather et al. (2016) \\
\hline $\begin{array}{l}\text { Induction with warm water }\left(48^{\circ} \mathrm{C}\right) \text { for } 3 \\
\text { minutes }\end{array}$ & Jiang et al. (2013) \\
\hline $\begin{array}{l}\text { Induction with maleic hydrazide }(500 \\
\mu \mathrm{M}) \text { for } 2 \text { minutes }\end{array}$ & Rizal et al. (2015) \\
\hline
\end{tabular}

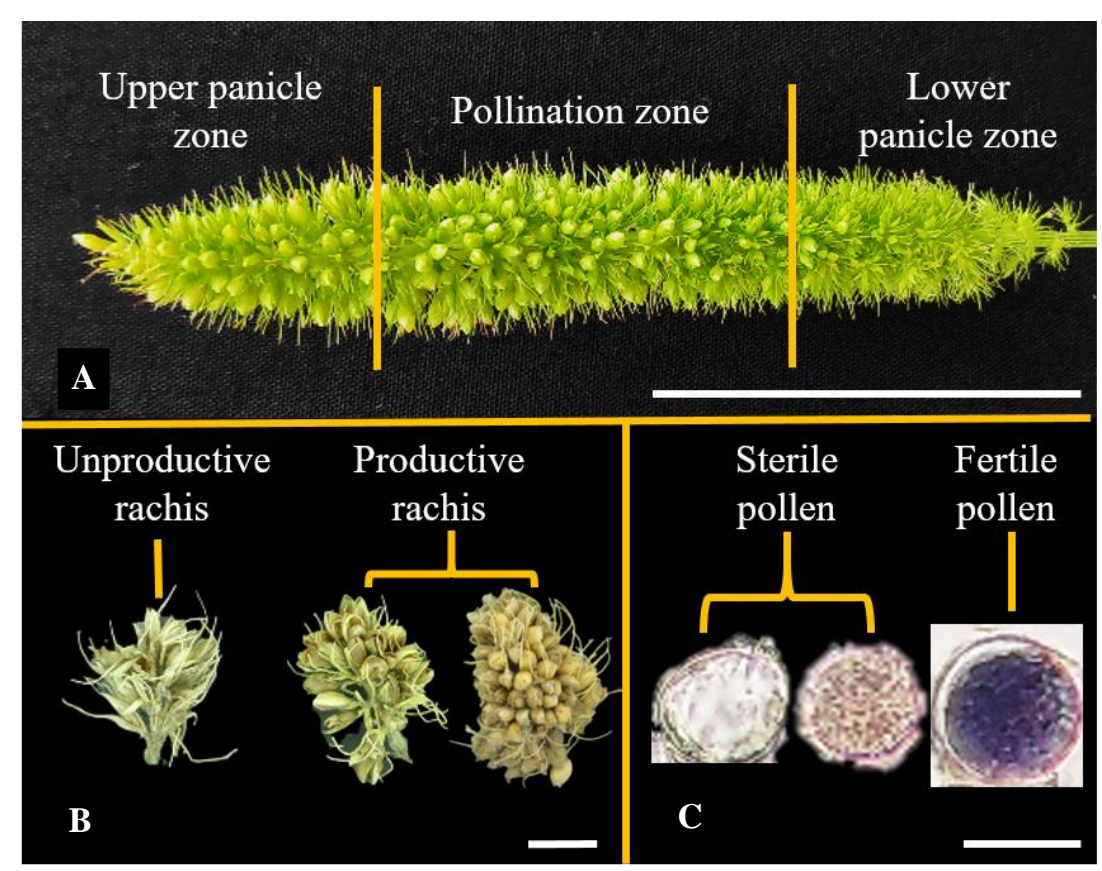

Figure 1. A. Panicle zone in foxtail millet; bar $=10 \mathrm{~cm}$, B. Rachis condition; bar $=5 \mathrm{~mm}$, C. Pollen condition; bar $20 \mu \mathrm{m}$ 
The observation of pollen was carried out between 05.00-06.00 am on the anthesis floret. The destruction of the florets and reproductive organs was carried out with a 2 $\times$ magnification binocular microscope (Olympus). Pollen staining was carried out with a $1 \% \mathrm{I}_{2} \mathrm{KI}$ solution and observed under an optical microscope (Olympus) with the magnification of $40 \times$. Dark and rounded pollen is fertile, while the shrunk and wrinkled pollen are sterile (Waheed et al. 2013). Analysis of variance and the least significant difference (LSD) test were conducted using the STAR software ver. 2.0.1.

\section{RESULTS AND DISCUSSION}

The purpose of male-sterile induction is to inhibit the development or sterilize the pollen grain for preventing selfing but does not disturb stigma receptivity. In the first sub-experiment, alcohol, warm water, and maleic hydrazide treatments were effective for killing pollen in the upper panicle zone and the pollination zone identified by color and shape after stained with $\mathrm{I}_{2} \mathrm{KI}$ (Figure 2.A; Table 2). $\mathrm{I}_{2} \mathrm{KI}$ is able to identify viability levels of pollen-based on starch level accumulation because it can bind the amylose with which turn dark blue color at the final reaction (Ulfah et al. 2016). Starch start accumulates at two days before anthesis in ICERI-5 and ICERI-6 foxtail millet genotypes and fully accumulated when anthesis (Nugroho et al. 2020, unpublished). The starch act as pollen metabolism factor that can be converted into sucrose for osmotic regulation or as the source of pollen energy that will be used for germination and help pollen pierce through the transmitting track to ovule, but it will be degraded when pollen damaged (Oliveira et al. 2015). In the present study, pollen staining method with $\mathrm{I}_{2} \mathrm{KI}$ widely used for various plant such rice (Waheed et al. 2013), lipstick flower (Ulfah et al. 2016), tea (Kumarihami et al. 2016), Cherimoya (Matsuda et al. 2016), Momordica species (Rathod et al. 2018), etc.

Died pollen affected the number of seeds in each rachis. All treatments were effective in producing unproductive rachis with different patterns (Figure 2.B; Tables 2 and 3). Alcohol treatment resulted in a pattern of few seeds in the upper panicle zone, $50 \%$ seeds in the pollination zone, and few seeds in the lower panicle zone. Warm water treatment resulting in few seeds in the upper panicle and the upper half of the pollination zone, and $100 \%$ seeds in the other half of pollination zone and lower panicle zone. Maleic hydrazide produced $50 \%$ seeds in the upper panicle and pollination zone, and $100 \%$ seeds in the lower panicle zone.

Lower panicle zone could have $100 \%$ seeds because it might escape from the treatment, i.e., the reproductive organs had not formed yet when the induction treatment was applied. Trimming the lower panicle zone before inducting is recommended to prevent escaping and pollinating the pollination zone. On the other hand, induction with warm water might cause pollination failures in the upper panicle zone and half upper pollination zone, so the seeds were not produced. Floret from the lower half of the pollination zone formed to be a seed. The pollen might come from the lower panicle zone, indicated by the lower half of the pollination zone took longer time to be pollinated than the lower panicle zone. Typically, the development of floret or seed in foxtail millet starts from the upper zone downward. However, the lower half of the pollination zone induced by warm water was an exception: it took longer to be pollinated than the lower panicle zone. Logically, if the lower half of the pollination zone escaped from the induction, then this zone should be pollinated faster than the lower panicle zone. Besides, alcohol treatment just prevents seed form from the upper panicle zone of the ICERI-6 genotype (Table 3).

The second sub-experiment showed the effectiveness of alcohol and maleic hydrazide in killing pollen in the pollination zone after trimming, followed by warm water treatment (Figure 3.A; Table 4). Sibbing with pollen from a donor plant helped pollination to occur, which was shown by the number of productive rachises and seeds formed in all treatments (60-100\%), except for alcohol treatment (lower than 20\%) (Figure 3.B; Table 4). The results indicated that the induction treatments of warm water and maleic hydrazide kept stigma receptive, as reported by Jiang et al. (2013) and Rizal et al. (2015). Seed formation failure can be due to panicle damage following the alcohol treatment (Figure 3.C; Table 4). The toxic effect of alcohol is well known for many years, especially when directly hit the plant (Maricle et al. 2014). Alcohol can degrade carbon chains and interrupt enzymatic activity in plants when alcohol was absorbed through the scar from trimming, resulting in tissue damage in panicles, including the stigma.

Alcohol male-sterile induction was an effective treatment for killing pollen for foxtail millet and also well known for grass family such rice (Rather et al. 2016), sugarcane (Soeprijanto and Sukarso 1989) and also for legume family such Alfalfa (Acquaah 2012). Pollen is composed of protein, fat, starch, etc. The protein, in general, is prolamin which is soluble in alcohol. Otherwise, the stigma is protected by glandular cells with an epidermis saved from alcohol (Soeprijanto and Sukarso 1989). But, in the second sub-experiment, trimming done before treatment, it causes a bad effect for the panicle (including stigma). For the next, trimming should be done after alcohol treatment and no more alcohol should be ensured in the panicle before trimming by the researcher. Also, the researcher should make sure there is no scar in the panicle before doing alcohol treatment.

Rizal et al. (2015) and Sharma and Sharma (2005) confirmed that maleic hydrazide which was classified as an antiauxin efficient in suppressing the pollen viability without disrupting stigma. That gametocide can kill $100 \%$ pollen in green millet, but some pollen were suspected of escaping from the treatment in foxtail millet so that the chances of self-pollination was still high. Optimization of the concentration or treatment time length or repeated application should be an alternative way to take advantage of maleic hydrazide for inducing male-sterile in foxtail millet. 


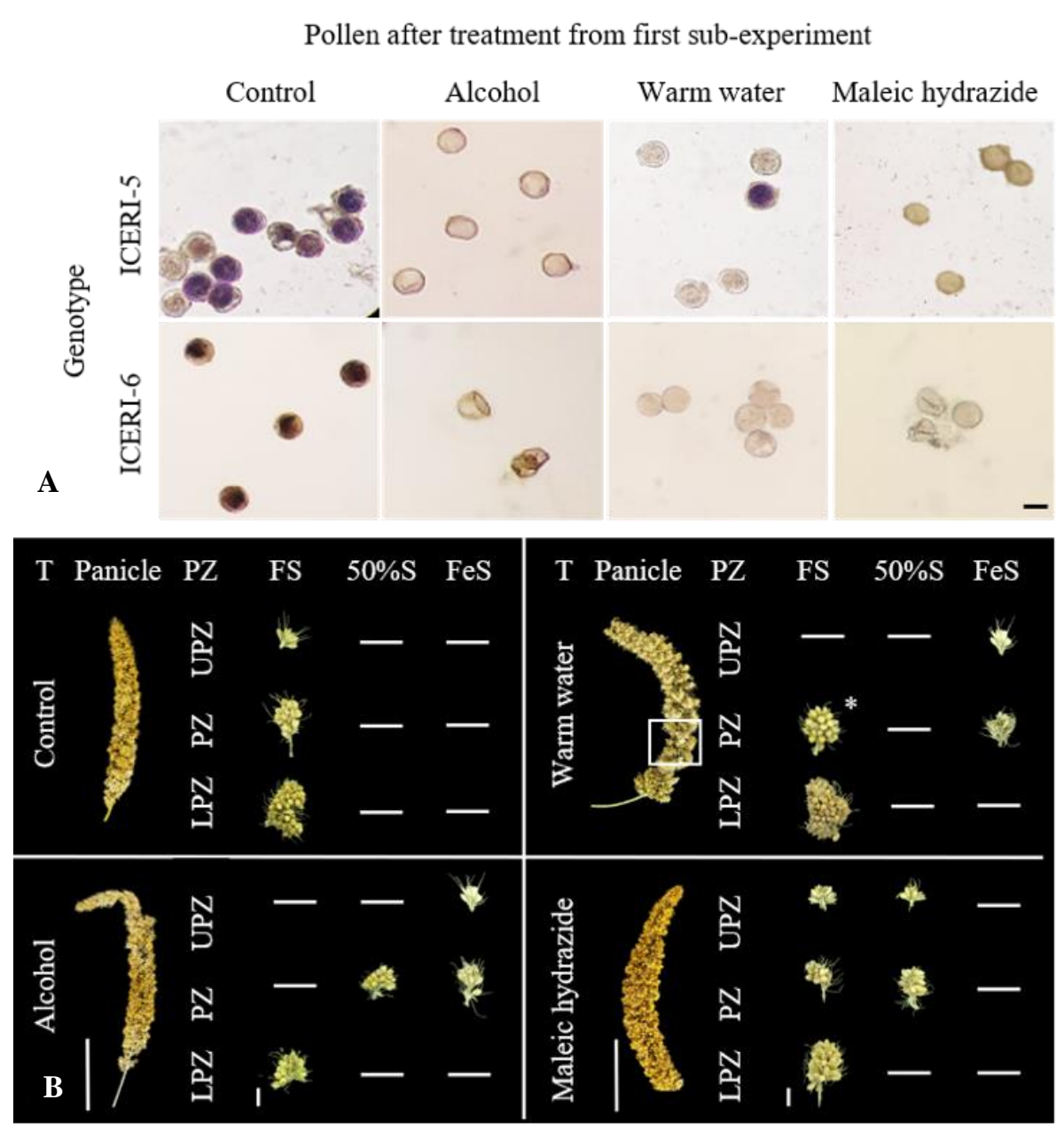

Figure 2. A. Pollen after treatment from first sub-experiment; *: full seeded in lower half of pollination zone (square marked area); bar $=20 \mu \mathrm{m}$, B. Panicle and rachis after treatment from first sub-experiment; T: treatment; PZ: panicle zone; UPZ: upper panicle zone; PZ: pollination zone; LPZ: lower panicle zone; FS: full seeded; $50 \% \mathrm{~S}$ : $50 \%$ seeded; FeS: few seeded; panicle bar $=5 \mathrm{~cm}$; rachis bar $=5 \mathrm{~mm}$

Table 2. Sterile pollen, unproductive rachis, and length of the panicle with full seeded from first sub-experiment

\begin{tabular}{|c|c|c|c|c|}
\hline \multirow{2}{*}{ Treatment } & \multicolumn{2}{|c|}{ Sterile pollen $(\%)$} & \multirow{2}{*}{$\begin{array}{l}\text { Unproductive rachis } \\
(\%)\end{array}$} & \multirow{2}{*}{$\begin{array}{c}\text { Length of full panicle } \\
(\%)\end{array}$} \\
\hline & Upper panicle zone & Pollination zone & & \\
\hline Control & $9.43 \mathrm{~b}$ & $9.90 \mathrm{c}$ & $0.00 \mathrm{~b}$ & $100.00 \mathrm{a}$ \\
\hline Alcohol & $96.83 \mathrm{a}$ & $94.15 \mathrm{a}$ & $59.16 \mathrm{a}$ & $27.15 \mathrm{bc}$ \\
\hline Warm water & $78.55 \mathrm{a}$ & $92.84 \mathrm{ab}$ & $62.77 \mathrm{a}$ & $48.23 \mathrm{~b}$ \\
\hline Maleic hydrazide & $84.83 \mathrm{a}$ & $78.16 \mathrm{~b}$ & $42.49 \mathrm{a}$ & $24.87 \mathrm{c}$ \\
\hline
\end{tabular}

Note: Means in the same column followed by the same letter are not significantly different based on LSD at 0.05 level

Table 3. Length of the panicle with $50 \%$ and few seeded, and floret or seed area from first sub-experiment.

\begin{tabular}{|c|c|c|c|c|c|c|}
\hline \multirow[t]{2}{*}{ Treatment } & \multicolumn{2}{|c|}{$\begin{array}{c}\text { Length of the panicle with } 50 \% \\
\text { seeded }(\%)\end{array}$} & \multicolumn{2}{|c|}{$\begin{array}{c}\text { Length of the panicle with few } \\
\text { seeded }(\%)\end{array}$} & \multicolumn{2}{|c|}{$\begin{array}{c}\text { Floret or seed area in the upper } \\
\text { panicle zone }\left(\mathrm{mm}^{2}\right)\end{array}$} \\
\hline & I5 & I6 & I5 & I6 & I5 & I6 \\
\hline Control & $0.00 \mathrm{c}$ & $0.00 \mathrm{~b}$ & $0.00 \mathrm{~b}$ & $0.00 \mathrm{~b}$ & $4.13 \mathrm{a}$ & $4.31 \mathrm{a}$ \\
\hline Alcohol & $63.35 \mathrm{~b}$ & $13.43 \mathrm{~b}$ & $12.38 \mathrm{~b}$ & $59.18 \mathrm{a}$ & $4.30 \mathrm{a}$ & $3.58 \mathrm{~b}$ \\
\hline Warm water & $0.00 \mathrm{c}$ & $0.00 \mathrm{~b}$ & $56.75 \mathrm{a}$ & $46.67 \mathrm{a}$ & $3.47 \mathrm{~b}$ & $3.40 \mathrm{~b}$ \\
\hline Maleic hydrazide & $75.21 \mathrm{a}$ & $75.69 \mathrm{a}$ & $0.00 \mathrm{~b}$ & $0.00 \mathrm{~b}$ & $4.02 \mathrm{a}$ & $4.20 \mathrm{a}$ \\
\hline
\end{tabular}

Note: I5: ICERI-5; I6: ICERI-6; means in the same column followed by the same letter are not significantly different based on LSD at 0.05 level 


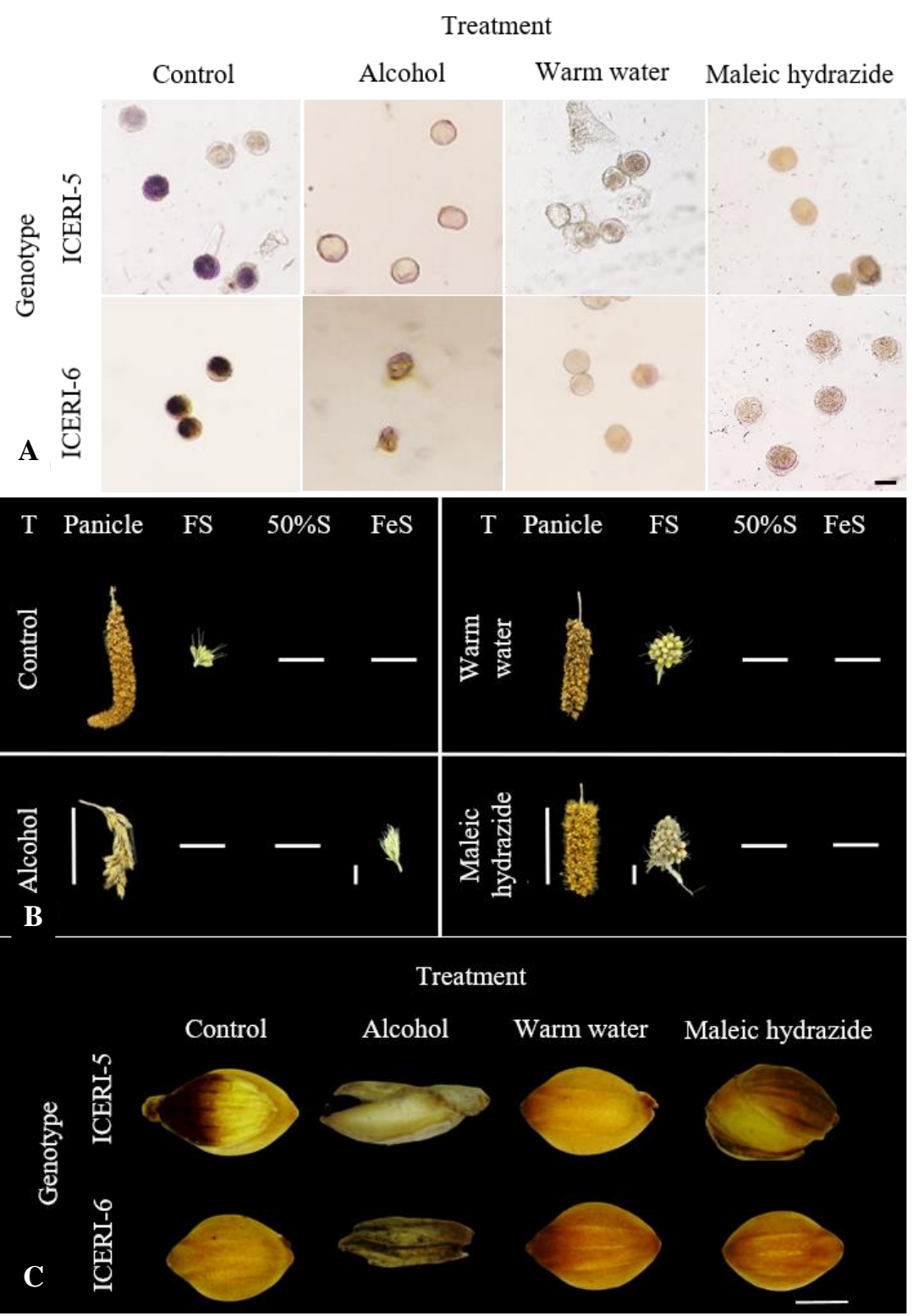

Figure 3. A. Pollen after treatment from second sub-experiment; bar $=20 \mu \mathrm{m}$, B. Panicle and rachis after treatment from second subexperiment; T: treatment; FS: full seeded; $50 \% \mathrm{~S}$ : $50 \%$ seeded; FeS: few seeded; panicle bar $=5 \mathrm{~cm}$; rachis bar $=5 \mathrm{~mm}, \mathrm{C}$. Floret or seed after treatment from second sub-experiment; bar $=1 \mathrm{~mm}$

Table 4. Sterile pollen, productive rachis, and floret or seed area from second sub-experiment.

\begin{tabular}{lccc}
\hline Treatment & $\begin{array}{c}\text { Sterile } \\
\text { pollen }(\%)\end{array}$ & $\begin{array}{c}\text { Productive } \\
\text { rachis }(\%)\end{array}$ & $\begin{array}{c}\text { Floret or } \\
\text { seed area } \\
\left(\mathbf{m m}^{2}\right)\end{array}$ \\
\hline Control & $4.83 \mathrm{c}$ & $100.00 \mathrm{a}$ & $4.21 \mathrm{a}$ \\
Alcohol & $97.79 \mathrm{a}$ & $18.43 \mathrm{c}$ & $3.05 \mathrm{~b}$ \\
Warm water & $81.69 \mathrm{~b}$ & $61.62 \mathrm{~b}$ & $4.28 \mathrm{a}$ \\
Maleic & $92.96 \mathrm{a}$ & $77.11 \mathrm{ab}$ & $4.13 \mathrm{a}$ \\
hydrazide & & & \\
\hline
\end{tabular}

Note: Means in the same column followed by the same letter are not significantly different based on LSD at 0.05 level
This study showed that warm water treatment was the best male-sterile induction treatment for foxtail millet because it can kill pollen while keeping the stigma receptive (Table 2 and 4 ) by depositing starch on pollen before anthesis so that it can prevent self-pollination in the upper panicle and the pollination zone. In addition, this method can keep stigma receptivity because the stigma is more tolerant to a higher temperature than the pollen (Aguiar et al. 2017). This treatment was relatively easy to apply, cheap, and eco-friendly which the waste does not contain synthetic chemicals. 


\section{ACKNOWLEDGEMENTS}

This work was supported by grant from Ministry of Research and Technology of the Republic of Indonesia through fundamental research scheme.

\section{REFERENCES}

Acquaah G. 2012. Principles of Plant Genetics and Breeding. 2nd ed. Wiley-Blackwell, Maryland.

Aguiar GA, Streck EA, Paulo HKF, Carolina G, Junior AMM, Maia LC. 2017. Hyperthermotherapy in the rice emasculation process. J Exp Agric Int 18 (4): 1-10.

Ambati K, Sucharitha KV. 2019. Millets-review on nutritional profiles and health benefits. Int J Recent Sci Res 10 (7): 33943-33948.

Ardie SW, Khumaida N, Nur A, Fauziah N. 2015. Early identification of salt tolerant foxtail millet (Setaria italica L. Beauv). Procedia Food Sci 3: 303-312. DOI: 10.1016/j.profoo.2015.01.033.

Dhivya AB, Subashini S, Chandrababu R, Ramalingam. 2015. Establishment of MilletDB: TNAU released millet varieties with their morphological traits. Int J Comput Appl 111 (14): 24-26.

Doust A, Diao X. 2017. Genetic and Genomics of Setaria. Springer, Gewerbestrasse.

Islam MS, Akhter MM, Sabagh AE, Liu LY, Nguyen NT, Ueda A, Masaoka Y, Saneoka H. 2011. Comparative studies on growth and physiological responses to saline and alkaline stresses of foxtail millet (Setaria italica L.) and proso millet (Panicum miliaceum L.). AJCS 5 (10): 1269-1277.

Jiang H, Barbier H, Thomas B. 2013. Methods for performing crosses in Setaria viridis, a new model system for the grass. J Vis Exp (80): 50527. DOI: $10.3791 / 50527$.

Kumarihami HMPC, Oh EU, Nesumi A, Song KJ. 2016. Comparative study on cross-compatibility between Camellia sinensis var. Sinensis (China type) and $C$. sinensis var. Assamica (Assam type) tea. Afr J Agric 11 (12): 1092-1101.

Lapuimakuni S, Khumaida N, Ardie SW. 2018. Short Communication: Evaluation of drought tolerance indices for genotype selection of foxtail millet (Setaria italica). Tropical Drylands 2 (2): 37-40. DOI: 10.13057/tropdrylands/t020201.

Lin S, Wang, V, Barchenger DW, Kumar S. 2017. Cytoplasmic Male Sterility (CMS) Breeding in Chilli Pepper. Swiscontact, Bogra.

Maricle BR, White SJ, Meraz A, Maforo NG, Biggs TN, Martin NM, Caudle KL. 2014. Effect of ethanol toxicity on enzyme activity in anaerobic respiration in plants. Trans Kans Acad Sci 117 (3-4): 237. 244.

Matsuda H, Higuchi H, Ogata T. 2016. Anatomical observation of pollen starch accumulation and pollen germinability as affected br pre- anthesis night temperature in cherimoya (Annona cherimola Mill.). Trop Agri Develop 60 (3): 155-161.

Nugraha Y, Munarso YP, Satoto. 2011. Pembentukan galur mandul jantan baru padi hibrida tahan penyakit hawar daun bakteri dan hama wereng batang coklat. Penelitian Pertanian Tanaman Pangan 30 (1): 9-16. [Indonesian]

Ojha E, Adhikari BB, Katuwal Y. 2018. Nutrient management trial on foxtail millet at Sundarbazar, Lamjung. Inst Agric Anim Sci 35: 8994.

Oliveira JMS, Martins MS, Dorneles MP, Freitas CC. 2015. Starch distribution in anthers, microspores, and pollen grains in Aechmea recurvata (Klotzscm.) L.B.Sm., Dyckia racinae L.B.Sm. and Tillandsia aeranthos (Loisel.) L.B.Sm. (Bromeliaceae). Acta Bot Bras 29 (1): 103-112. DOI: 10.1590/0102-33062014abb3698

Rather SA, Pandey ID, Panda GS, Kumar S. 2016. Relative efficiency of different emasculation method in rice (Oryza sativa L.). Environ Ecol 35 (3B): 2205-2208

Rathod V, Behera TK, Munshi AD, Durgesh K, Jat GS, Krishnan BG, Sharma N. 2018. Pollen viability and in vitro pollen germination studies in Momordica species and their intra and interspecific hybrids. Int J Chem Stud 6 (6): 32-40.

Rizal G, Acebron K, Mogul R, Karki S, Larazo N, Quick WP. 2013. Study of flowering pattern in Setaria viridis, proposed model species for C4 photosynthesis research. J Bot 2013: 1-7. DOI: $10.1155 / 2013 / 592429$

Rizal G, Karki S, Garcia R, Nikki L, Alcasid M, Quick WP. 2015. The use of maleic hydrazide for effective hybridization of Setaria viridis. PLoS One 10 (4): e0125092. DOI: 10.1371/journal.pone.0125092

Sharma Y, Sharma SN. 2005. Chemical hybridizing agents (CHA) - a tool for hybrid seed production - a review. Agric Rev 26 (2): 114-123.

Sharma P, Thakur S, Negi R. 2019. Recent advances in breeding of tomato-a review. Int J Curr Microbiol App Sci 8 (3): 1275-1283.

Soeprijanto, Sukarso G. 1989. Emasculation of sugarcane (Saccharum spp) tassel using alcohol emmersion. Proc Intl Soc Sugar Cane Technol 20: 860-863.

Ulfah SM, Dorly, Rahayu S. 2016. Perkembangan bunga dan uji viabilitas serbuk sari bunga lipstik Aeschynanthus radicans var. 'Monalisa' di Kebun Raya Bogor. Buletin Kebun Raya 19 (1): 21-32. [Indonesian]

Waheed A, Habib A, Fida MA, Hamid FS, Shah AH, Safi FA, Ali H. 2013. Pollen sterility in wide crosses derivatives of rice (Oryza sativa L.). J Mater Environ Sci 4 (3): 404-409.

Widyawan MH, Khumaida N, Kitashiba H, Nishio T, Ardie SW. 2018. Optimization of dot-blot SNP analysis for detection of drought or salinity stress associated marker in foxtail millet (Setaria italica L.). SABRAO J Breed Genet 50 (1): 72-84.

Yin SY, Kuo SM, Chen YR, Tsai YC, Wu YP, Lin YR. 2019. Genetic variation of physicochemical properties and digestibility of foxtail millet (Setaria italica) landraces of Taiwan. Molecules 24 (23): 4323. DOI: 10.3390/molecules24234323. 